\title{
Effects of Rootstock and Budding Height on Bacterial Canker in French Prune
}

\author{
R. J. Sayler, Department of Plant Pathology, University of California, Davis 95616; S. M. Southwick, J. T. \\ Yeager, and K. Glozer, Department of Pomology, University of California, Davis; E. L. Little, Department Plant \\ Pathology, University of Georgia, Athens 30602; and B. C. Kirkpatrick, Department of Plant Pathology, \\ University of California, Davis
}

\begin{abstract}
Sayler, R. J., Southwick, S. M., Yeager, J. T., Glozer, K., Little, E. L., and Kirkpatrick, B. C. 2002. Effects of rootstock and budding height on bacterial canker in French prune. Plant Dis. $86: 543-546$

Bacterial canker is one of the most economically important diseases of stone fruit trees, including 'French' prune (Prunus domestica). Field trials were conducted to evaluate the effect of rootstock selection and budding height on the incidence and severity of bacterial canker in four orchards with low to high disease pressure. Treatments included French prune scions lowgrafted on 'Lovell' peach (Prunus persica) rootstocks as well as Myrobalan 29C (Prunus cerasifera) plum rootstocks grafted at 15,50 , and $90 \mathrm{~cm}$ above the rootstock crown. Another treatment consisted of growing Myrobalan 29C plum rootstocks in the field for one growing season, then field-grafting French prune buds onto rootstock scaffolds. Lovell peach rootstock provided the greatest protection from bacterial canker as measured by disease incidence and tree mortality in all orchards. Field-budded rootstocks and rootstocks grafted at the highest budding height provided moderate levels of resistance to bacterial canker. These treatments reduced the incidence but not the severity of disease.
\end{abstract}

Additional keywords: Prunus armeniaca, Prunus avium, Pseudomonas syringae pv. morsprunorum, Pseudomonas syringae pv. syringae

Bacterial canker, caused by Pseudomonas syringae pv. syringae Van Hall, is a serious disease of prune (Prunus domestica L., cv. French) and other stone fruits in California. This disease occurs worldwide where stone fruits are grown $(5,8,9,11,15)$ and often results in limb die back and tree mortality. Disease development on stone fruit trees can be affected by many factors, including soil depth, low soil $\mathrm{pH}$, soil fertility, tree age, tree nutrition, rootstock selection, cultural practices such as budding height, the presence of ring nematode (Criconemella xenoplax (Raski)), and environmental factors such as rainfall and freezing temperatures $(10,12,13,19)$.

Traditional methods for minimizing losses to bacterial canker have included soil fumigation (3) and the use of resistant 'Lovell' peach ( $P$. persica (L.) Batsch) rootstocks $(4,12,21)$. One effective soil fumigant, methyl bromide, may be eliminated in the future. Lovell peach

Corresponding authors: R. J. Sayler and B. C. Kirkpatrick

E-mail: rjsayler@ucdavis.edu and

bckirkpatrick@ucdavis.edu

Funding for this research was provided by the California Prune Board.

Accepted for publication 10 January 2002.

Publication no. D-2002-0307-01R

(C) 2002 The American Phytopathological Society rootstocks have limited usefulness in the heavy, poorly drained soils in California's Sacramento Valley because of their susceptibility to Phytophthora root rot. Myrobalan 29C ( $P$. cerasifera Ehrh.), a commonly used plum rootstock for French prune, is more resistant to Phytophthora root rot, which may occur on trees grown in finely textured, poorly drained soils, but French prune trees grown on this plum rootstock are more susceptible to bacterial canker.

High-budding cherry scions onto scaffold limbs of mahaleb ( $P$. mahaleb L.) or mazzard (P. avium L.) rootstocks improved resistance to bacterial canker over the traditional low-budded rootstocks $(1,2,7)$. Prunier et al. 1999 (16) reported that apri$\cot (P$. armeniaca L.) field-grafted onto Myrobalan B, Mariana GF 8-1, P. domestica 'Green Gage', or peach GF 305-1 rootstocks at $1.4 \mathrm{~m}$ above the soil line provided improved vigor and superior resistance to bacterial canker compared with scions grafted on these rootstocks near the soil line. Several researchers in England found that increasing the budding height of plum scions from just above the soil line to the crotch or scaffolds on Myrobalan B rootstocks improved resistance to bacterial canker caused by Pseudomonas syringae pv. morsprunorum Wormald $(14,17,20)$. In this study, we tested the hypothesis that budding height, rootstock selection, and field budding onto scaffolds of established rootstocks may affect the vigor and subsequent resistance of cv. French prune to bacterial canker.

\section{MATERIALS AND METHODS}

Experimental design. Four growermanaged French prune orchards in the Sacramento Valley of California that had previously lost trees to bacterial canker were used in this study. Budding height and rootstock selection treatments were applied to trees that were randomly interplanted in these orchard sites as replacements for trees that had previously died from bacterial canker. Three treatments consisted of French prune scions budded on Myrobalan 29C plum rootstock at 15, 50 , and $90 \mathrm{~cm}$ above the soil line in the nursery and planted in the field in spring 1995. These three rootstock treatments are referred to as low-budded, medium-budded, and high-budded, respectively. In addition, Lovell peach rootstocks were nursery grafted at $15 \mathrm{~cm}$ above the soil line with French prune scions and planted in the same fashion. Last, Myrobalan 29C rootstocks were planted in the field in May 1995 and four to six rootstock scaffolds were T-budded with French prune buds in September 1995 and referred to as field budded trees. In all, 70 to 80 trees were evaluated per treatment for all orchards combined except the field-grown rootstock treatment, for which 48 trees were evaluated.

Measures. Tree mortality and incidence and severity of bacterial canker were assessed in May and July of years 1996 to 1999. Disease severity was determined using a visual rating system of $0=$ healthy, $1=$ one point of infection, $2=$ less than half of the trunk cambium infected, $3=$ more than half of the trunk cambium infected, $4=$ scaffold death, and $5=$ tree death. Mean disease severity for each treatment was determined by evaluating only those trees that expressed disease symptoms with ratings of 1 through 5; thus, healthy trees were not included in calculations of mean disease severity. Final analyses of all disease measures were performed on the data from 1999. Tree vegetative vigor was determined by calculating the trunk cross-sectional area from the trunk circumference. The trunk circumference was measured at $30 \mathrm{~cm}$ above the soil line at leaf fall in 1996 through 1998. Trunk circumference was not measured in 1999 because many trees had died from bacterial canker by 1999. Analysis of trunk 
circumference was performed only on the data collected in 1998.

Statistical analysis. Treatments were arranged in a randomized complete block design with orchard sites as blocks. The general linear models procedure of SAS (Statistical Analysis Systems software, release 7.0; SAS Institute, Cary, NC) was used for analysis of variance (ANOVA) of all main effects using weighted analysis. Main effects were analyzed using a mixed model with treatment effects designated as fixed and location effects assigned as random (18). The lsmeans procedure of SAS was used to perform mean separation procedures for disease rating and vigor means. The treatment by orchard interaction mean square was used as the error term for mean separation when this interaction was significant $(P<0.05)$. Measurements of trunk cross-sectional area were transformed using natural $\log$ prior to the ANOVA and mean separation procedures. Treatment and location means for vigor were calculated from the original untransformed data. Disease rating and vegetative growth means were considered to be significantly different if $P<0.05$.

\section{RESULTS}

Effect of rootstock and budding height on disease incidence and severity. An ANOVA of disease rating for bacterial canker showed significant effects of treat-

Table 1. Analysis of variance of bacterial canker disease ratings for 'French' prune

\begin{tabular}{lrccc}
\hline Source & df & Mean square & $\boldsymbol{F}$ value & $\boldsymbol{P r}>\boldsymbol{F}$ \\
\hline Rootstock \& budding treatment (R/B) & 4 & 10.6 & 30.5 & 0.0001 \\
Orchard (O) & 3 & 12.1 & 33.3 & 0.0001 \\
R/B $\times$ O & 12 & 1.3 & 3.6 & 0.0001 \\
Error & 325 & 1.0 & $\ldots$ & $\ldots$ \\
\hline
\end{tabular}

Table 2. Disease rating, incidence, and mortality due to bacterial canker disease in all rootstock treatments in the four 'French' prune orchard sites ${ }^{x}$

\begin{tabular}{lcccc}
\hline Orchard & Rating $^{\mathbf{y}}$ & Incidence (\%) & Mortality (\%) & $\boldsymbol{n}^{\mathbf{z}}$ \\
\hline 1 & $3.8 \mathrm{a}$ & 78 & 65 & 85 \\
2 & $2.8 \mathrm{~b}$ & 67 & 46 & 99 \\
3 & $1.2 \mathrm{c}$ & 48 & 32 & 82 \\
4 & $0.8 \mathrm{c}$ & 29 & 11 & 79 \\
\hline
\end{tabular}

${ }^{\mathrm{x}}$ Means followed by different letters are significantly different $(P<0.05)$ using lsmeans of SAS with the treatment by location mean square as the error term.

${ }^{y}$ Disease rating of 0 (healthy) to 5 (dead).

${ }^{\mathrm{z}}$ Value includes both healthy and diseased trees.

Table 3. Effects of rootstock and budding treatments on disease rating, incidence and mortality due to bacterial canker disease in 'French' prune trees in all four orchard sites combined ${ }^{\mathrm{w}}$

\begin{tabular}{lcccc}
\hline Treatment $^{\mathbf{x}}$ & Rating $^{\mathbf{y}}$ & Incidence (\%) $^{\text {Mortality (\%) }}$ & $\boldsymbol{n}^{\mathbf{z}}$ \\
\hline Low-budded & $3.2 \mathrm{a}$ & 74 & 56 & 73 \\
Medium-budded & $2.8 \mathrm{a}$ & 70 & 48 & 82 \\
High-budded & $2.8 \mathrm{a}$ & 66 & 44 & 73 \\
Field-budded & $1.8 \mathrm{a}$ & 54 & 38 & 48 \\
Lovell & $0.4 \mathrm{~b}$ & 13 & 9 & 69
\end{tabular}

${ }^{\mathrm{w}}$ Means followed by different letters are significantly different $(P<0.05)$ using lsmeans of SAS with the treatment by location mean square as the error term.

x Budding heights on Myrobalan 29C: low-budded $=15 \mathrm{~cm}$, medium-budded $=50 \mathrm{~cm}$, high-budded $=90 \mathrm{~cm}$ above soil line, and field-budded $=$ T-budded on scaffold branches of Myrobalan 29C rootstocks grown in the field 4 months.

${ }^{y}$ Disease rating of 0 (healthy) to 5 (dead).

${ }^{\mathrm{z}}$ Value includes both healthy and diseased trees.

ment and location as well as a significant interaction between treatment and locations (Table 1). Disease pressure, as measured by disease rating, incidence, and mortality, varied considerably among the four orchard sites (Table 2). Orchard 1 had the greatest disease incidence and tree mortality and orchards 3 and 4 the least (Table 2). Lovell peach rootstock provided the best protection from bacterial canker for the French prune scion, based on means of all orchards combined (Table 3), and it had the lowest incidence of disease in all four orchard sites (Table 4). Scions on the lowbudded Myrobalan 29C rootstock had a mean disease rating higher than all other treatments (Table 3). Trees low-budded in the nursery on Myrobalan 29C had the highest incidence of disease based on means for all orchards combined (Table 3) and in two of the four individual orchard sites that had the highest disease pressure (Table 4). Mean tree mortality for all orchards combined was greatest on the lowbudded Myrobalan 29C rootstock and least on the Lovell peach rootstock (Table 3). Lovell peach rootstock provided the greatest protection against bacterial canker in two of the four individual orchards (Table 4). Incidence of bacterial canker on fieldbudded Myrobalan 29C was lower than any nursery-budded tree on the same rootstock when data from all orchard sites were combined (Table 3), and in all individual orchards except orchard 4 (Table 4). Tree mortality among treatments generally followed the same order as disease incidence but was 0 to $41 \%$ lower than disease incidence across individual orchard sites (Table 4). The order among treatments over all orchards combined (Table 3) matched the order of disease incidence and tree mortality among all but the mediumbudded treatment in orchards 1 and 2, which had the highest disease incidence (Table 4). The effects of rootstock and budding height on disease incidence and tree mortality in the two orchards with the lowest disease incidence were more variable with respect to the treatment effects. In other words, the beneficial effects of Lovell rootstock and field-budding and high-budding Myrobalan rootstocks were greatest in orchards with the greatest level of bacterial canker (Table 4).

Table 4. Effect of rootstock and budding treatments on the incidence and mortality of bacterial canker disease in 'French' prune trees growing in four or-

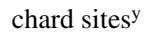

\begin{tabular}{|c|c|c|c|c|c|c|c|c|c|c|c|c|}
\hline \multirow[b]{2}{*}{ Treatment $^{\mathrm{z}}$} & \multicolumn{3}{|c|}{ Orchard 1} & \multicolumn{3}{|c|}{ Orchard 2} & \multicolumn{3}{|c|}{ Orchard 3} & \multicolumn{3}{|c|}{ Orchard 4} \\
\hline & $\mathbf{R}$ & I & M & $\mathbf{R}$ & I & $\mathbf{M}$ & $\mathbf{R}$ & I & $\mathbf{M}$ & $\mathbf{R}$ & I & $\mathbf{M}$ \\
\hline Low-budded & $4.3 \mathrm{a}$ & 88 & 81 & $4.5 \mathrm{a}$ & 100 & 59 & $2.6 \mathrm{a}$ & 56 & 44 & $1.4 \mathrm{a}$ & 47 & 17 \\
\hline Medium-budded & $4.3 \mathrm{a}$ & 89 & 78 & $3.6 \mathrm{ab}$ & 86 & 77 & $2.4 \mathrm{a}$ & 67 & 39 & $0.6 \mathrm{a}$ & 24 & 6 \\
\hline High-budded & $3.9 \mathrm{a}$ & 85 & 65 & $3.4 \mathrm{ab}$ & 78 & 50 & $3.4 \mathrm{a}$ & 72 & 50 & $0.7 \mathrm{a}$ & 24 & 6 \\
\hline Field-budded & $3.8 \mathrm{a}$ & 83 & 66 & $1.2 \mathrm{bc}$ & 33 & 22 & $1.2 \mathrm{a}$ & 25 & 13 & $1.5 \mathrm{a}$ & 46 & 23 \\
\hline Lovell & $1.2 \mathrm{~b}$ & 31 & 23 & $0.3 \mathrm{c}$ & 10 & 5 & $0.3 \mathrm{a}$ & 10 & 5 & $0.3 \mathrm{a}$ & 7 & 7 \\
\hline
\end{tabular}

y Disease measures for individual orchards: $\mathrm{R}=$ disease rating of 0 (healthy) to 5 (dead), $\mathrm{I}=$ percentage of trees with some incidence of bacterial canker, $\mathrm{M}=$ percentage of trees that died. Means within each column followed by different letters are significantly different $(P<0.05)$ using lsmeans of SAS.

${ }^{\mathrm{z}}$ Grafting heights on Myrobalan 29C: low-budded $=15 \mathrm{~cm}$, medium-budded $=50 \mathrm{~cm}$, high-budded $=90 \mathrm{~cm}$ above soil line, field-budded $=$ French prune buds grafted onto scaffold branches of Myrobalan 29C rootstocks that grew in the field for 4 months prior to grafting. 
ANOVA of disease severity revealed that only the effect of orchard was significant (Table 5). There was no significant difference in disease severity among rootstock treatments, although only 8 of 69 French prune trees on Lovell peach rootstock developed bacterial canker (Table 6). Disease severity among orchard sites 1, 2, and 3 was not significantly different but disease severity was significantly lower at orchard site 4 compared with the other three sites (Table 7).

Tree vigor. ANOVA of trunk cross-sectional area indicated that tree vigor was significantly affected by rootstock, budding height, orchard location, and the interaction between treatment and location (Table 8). Vegetative growth was greatest in trees grafted on Lovell peach rootstocks and high budded Myrobalan 29C and least on trees field budded on Myrobalan 29C plum rootstock based on combined data from all orchard sites (Table 9). Measurements of trunk cross-sectional area were not analyzed after 1998 because of high tree mortality due to bacterial canker. Significant differences in tree vigor were detected among three of the four test orchard sites (Table 10). Orchard 4 had the greatest trunk cross-sectional area (Table 10) and the least bacterial canker (Table 7). Tree growth in specific orchard sites (Table 10) was not related to the disease incidence and tree mortality in the individual orchard (Table 4). Although disease severity was lowest in orchard site 4, which had the best vegetative growth, the effects of orchard location on vegetative growth and disease did not appear to be associated.

\section{DISCUSSION}

Low-budded Lovell peach was the most effective rootstock treatment of those tested in preventing bacterial canker in French prune. This rootstock has previously been reported to be superior to all others in controlling bacterial canker damage in peach (21), Italian prune (2), and French prune (6). Myrobalan 29C plum rootstock high-budded in the nursery or scaffold-budded in the field also provided some resistance to bacterial canker, al- though disease incidence was not significantly different from low-budded trees on the same rootstock, which is the standard practice in the nursery industry. Scaffoldbudding rootstocks in the field also proved superior to nursery grafting at the soil line in sweet cherry (Prunus avium; 1,2,7), apricot (P. armeniaca; 16), and plum $(P$. domestica; 14,17,20).

Reduction in disease incidence and tree mortality was the primary means by which the Lovell rootstock, budding height, and field-budded treatments affected disease. No significant differences were detected in the severity of disease among these treatments (Table 6). The Lovell peach rootstock and, to a lesser extent, the nursery high-budded and the field-budded treatments on Myrobalan 29C, appeared to provide resistance by preventing the initial infection by the pathogen. Once infection by Pseudomonas syringae pv. syringae is visible, rootstock and budding height appear to have little effect in mitigating the severity of the infection.

The effect of rootstock and budding height was most pronounced in the two orchard sites (orchard 1 and 2) with the greatest disease incidence and tree mortality (Table 4). Lovell peach rootstock provided the greatest reduction in disease incidence and tree mortality in orchard 1, which had the greatest tree mortality due to bacterial canker. The beneficial effects of Lovell peach rootstock, and to a lesser extent both the field-grafted and highgrafted treatments, were most apparent in orchards 1 and 2, which had the greatest disease pressure. The beneficial effects of Lovell and field-budded Myrobalan rootstocks were less in orchards 3 and 4, which had lower levels of disease. This shows the possible benefit of using these treatments in orchard sites with the potential for developing severe bacterial canker. Differences between the rootstock and budding height treatments in orchard sites with low disease incidence and tree mortality did not always follow the overall order of rootstock effects (Table 3) on bacterial canker because disease was less common in orchards 3 and 4 . The nature of the disease

Table 5. Analysis of variance of effects of rootstock and budding treatment on disease severity of 'French' prune trees showing symptoms of bacterial canker

\begin{tabular}{lrccc}
\hline Source & df & Mean square & $\boldsymbol{F}$ value & $\boldsymbol{P r}>\boldsymbol{F}$ \\
\hline Rootstock \& budding treatment $(\mathrm{R} / \mathrm{B})$ & 4 & 0.75 & 0.8 & 0.5609 \\
Orchard $(\mathrm{O})$ & 3 & 4.71 & 4.7 & 0.0034 \\
R/B $\times$ O & 11 & 0.33 & 0.3 & 0.9770 \\
Error & 174 & 1.00 & $\ldots$ & $\ldots$ \\
\hline
\end{tabular}

Table 8. Analysis of variance of trunk cross-sectional area for 'French' prune

\begin{tabular}{lrccc}
\hline Source & df & Mean square & $\boldsymbol{F}$ value & $\boldsymbol{P r}>\boldsymbol{F}$ \\
\hline Rootstock \& budding treatment (R/B) & 4 & 8.46 & 9.4 & 0.0001 \\
Orchard (O) & 3 & 9.90 & 10.9 & 0.0001 \\
$\mathrm{R} / \mathrm{B} \times \mathrm{O}$ & 12 & 1.86 & 1.7 & 0.0001 \\
Error & 174 & 1.00 & $\ldots$ & $\ldots$ \\
\hline
\end{tabular}

resistance mechanisms imparted by Lovell peach rootstock and high grafting on Myrobalan 29C are unknown.

Disease incidence and tree mortality varied considerably among the four orchard sites due, in part, to differences in soil and horticultural conditions at each site. A different grower managed each orchard; although management practices varied somewhat among orchards, they were uniform and consistent within each orchard. The nature of the factors that produced greater bacterial canker disease in orchard 1 and 2 versus orchards 3 and 4 is unknown. Ring nematodes were present in all four orchards (data not shown) and similar horticultural practices were used in all four orchards. Differences in soil composition may have accounted for some of the observed differences among the orchards used in this study. However, numerous abiotic and biological factors have been implicated in predisposing Prunus trees to bacterial canker $(5,10,12$, $13,15,19)$ and these or other unknown factors may have contributed to the treatment variation among the four orchard sites in this study.

Table 6. Effects of rootstock and propagation method on the severity of bacterial canker among French prune trees showing symptoms of disease in all four test orchards combined ${ }^{\mathrm{x}}$

\begin{tabular}{lcc}
\hline Treatment $^{\mathbf{y}}$ & Severity $^{\mathbf{z}}$ & $\begin{array}{c}\text { Diseased/ } \\
\text { total trees }\end{array}$ \\
\hline Low-budded & $4.7 \mathrm{a}$ & $54 / 73$ \\
Medium-budded & $4.6 \mathrm{a}$ & $57 / 82$ \\
High-budded & $4.5 \mathrm{a}$ & $48 / 73$ \\
Field-budded & $4.4 \mathrm{a}$ & $26 / 48$ \\
Lovell & $3.7 \mathrm{a}$ & $8 / 69$ \\
\hline
\end{tabular}

${ }^{x}$ Means followed by the same letters are not significantly different $(P<0.05)$ using Tukey's test.

${ }^{y}$ Grafting heights on Myrobalan 29C: lowbudded $=15 \mathrm{~cm}$, medium-budded $=50 \mathrm{~cm}$, high-budded $=90 \mathrm{~cm}$ above soil line, fieldbudded $=$ French prune buds grafted onto limbs of Myrobalan 29C rootstock that grew in the field for 4 months prior to grafting.

${ }^{\mathrm{z}}$ Disease severity rating of 1 (one point of infection) to 5 (dead), only diseased trees were used to determine the disease severity rating. Values are means of all four orchards combined.

Table 7. Severity of bacterial canker disease in the four test orchards ${ }^{y}$

\begin{tabular}{lcc}
\hline Orchard & $\begin{array}{c}\text { Severity } \\
\text { rating }\end{array}$ & $\begin{array}{c}\text { Diseased/ } \\
\text { total trees }\end{array}$ \\
\hline 1 & $4.8 \mathrm{a}$ & $66 / 85$ \\
2 & $4.4 \mathrm{a}$ & $66 / 99$ \\
3 & $4.3 \mathrm{a}$ & $39 / 82$ \\
4 & $3.0 \mathrm{~b}$ & $22 / 79$ \\
\hline
\end{tabular}

${ }^{y}$ Means followed by different letters are significantly different $(P<0.05)$ using Tukey's test.

${ }^{\mathrm{z}}$ Disease severity rating of 1 (one point of infection) to 5 (dead), only diseased trees were used to determine the disease severity rating. 
Table 9. Effects of rootstock and budding height on trunk cross-sectional area (CSA) of all trees at the four test orchard sites measured in 1998

\begin{tabular}{|c|c|c|c|c|c|c|}
\hline \multirow[b]{2}{*}{ Treatment $^{\mathrm{x}}$} & \multirow[b]{2}{*}{ Mean CSA $\left(\mathrm{cm}^{2}\right)^{y}$} & \multirow[b]{2}{*}{$n^{\mathbf{z}}$} & \multicolumn{4}{|c|}{ Orchard $^{w}$} \\
\hline & & & 1 & 2 & 3 & 4 \\
\hline Lovell & $35.0 \mathrm{a}$ & 67 & $40.5 \mathrm{a}$ & $32.6 \mathrm{a}$ & $28.9 \mathrm{a}$ & $42.5 \mathrm{a}$ \\
\hline High-budded & $31.3 \mathrm{ab}$ & 64 & $26.0 \mathrm{ab}$ & $31.6 \mathrm{ab}$ & $25.0 \mathrm{ab}$ & $40.1 \mathrm{~b}$ \\
\hline Medium-budded & $27.7 \mathrm{ab}$ & 70 & $33.7 \mathrm{ab}$ & $24.5 \mathrm{bc}$ & $18.3 \mathrm{ab}$ & $37.3 \mathrm{~b}$ \\
\hline Low-budded & $25.8 \mathrm{~b}$ & 64 & $28.3 \mathrm{~b}$ & $25.0 \mathrm{bc}$ & $18.0 \mathrm{bc}$ & $33.8 \mathrm{~b}$ \\
\hline Field-budded & $12.9 \mathrm{c}$ & 32 & $9.8 \mathrm{c}$ & $15.1 \mathrm{c}$ & $13.1 \mathrm{c}$ & $13.7 \mathrm{c}$ \\
\hline
\end{tabular}

${ }^{w}$ Means within each column followed by different letters are significantly different $(P<0.05)$ using lsmeans of SAS.

x Budding heights on Myrobalan 29C: high-budded $=90 \mathrm{~cm}$ above soil line, low-budded $=15 \mathrm{~cm}$, medium-budded $=50 \mathrm{~cm}$, field-budded $=$ French prune buds grafted onto scaffold branches of Myrobalan 29C rootstocks that grew in the field for 4 months prior to grafting.

y Means within the column followed by different letters are significantly different $(P<0.05)$ using lsmeans of SAS with the treatment by location mean square as the error term.

z Value represents living trees only among all four orchard sites in 1998.

Table 10. Mean cross-sectional trunk area (CSA) of all rootstock treatments at each orchard site measured in $1998^{\mathrm{y}}$

\begin{tabular}{lcr}
\hline Orchard & Mean CSA $\left(\mathbf{c m}^{\mathbf{2}}\right)$ & $\boldsymbol{n}^{\mathbf{z}}$ \\
\hline 1 & $27.8 \mathrm{~b}$ & 47 \\
2 & $27.3 \mathrm{~b}$ & 102 \\
3 & $21.6 \mathrm{c}$ & 70 \\
4 & $34.8 \mathrm{a}$ & 78 \\
\hline
\end{tabular}

y Means within the column followed by different letters are significantly different $(P<$ 0.05) using lsmeans of SAS with the treatment by location mean square as the error term.

$\mathrm{z}$ Value includes living trees only.

French prune budded on Lovell peach rootstock produced the greatest vegetative growth, and this rootstock was superior to low-budded Myrobalan 29C plum rootstock in reducing the incidence of bacterial canker. The relationship between the reduction in incidence of bacterial canker and growth appeared to be generally positive, except for field-budded trees. However, the relationship between increased growth and reduction in bacterial canker disease rating could not be confirmed statistically because of the variation in the data. Previous studies on French prune (6) and peach (21) showed no relationship between vegetative growth and susceptibility to bacterial canker and peach tree short life, respectively. Prunier et al. (16) reported that apricots grafted at $1.4 \mathrm{~m}$ above the soil line generally had greater vigor than those grafted on the same rootstock at the soil line. This is in contrast with the field-budded treatment in this study that produced the least vegetative growth but provided a modest reduction in bacterial canker. The poor vigor in this field-budded rootstock treatment was most likely because the Myrobalan rootstock was severely pruned and T-budded in September 1995. This grafting technique encouraged the rootstock to profusely produce shoot suckers, which then were pruned off. The timing and method of grafting probably reduced the vigor of these trees due to the repeated pruning that was required to eliminate rootstock suckers. Whip-grafting of field-grown rootstocks in the spring has provided superior vigor and perhaps even better protection from bacterial canker ( $\mathrm{R}$. J. Sayler, unpublished data). Even so, field-budded rootstocks along with the high-budded, nursery-grafted trees provided a modest reduction in disease incidence and tree mortality due to bacterial canker among trees grown on Myrobalan 29C. Field-budded or high-budded nursery trees on Myrobalan 29C plum rootstocks may provide some measure of control for bacterial canker where Lovell peach rootstock is unsuitable, such as orchards with fine-textured, poorly drained soils where poor aeration and soilborne diseases such as Phytophthora root rot may occur.

\section{ACKNOWLEDGMENTS}

We thank University of California Cooperative Extension Farm Advisors W. Olsen, W. Krueger, and R. Buchner for their assistance in identifying the orchards used in this study.

\section{LITERATURE CITED}

1. Cameron, H. R. 1960. Susceptibility of mazzard seedlings to Pseudomonas syringae. (Abstr.) Phytopathology 50:82.

2. Cameron, H. R. 1971. Effect of root or trunk stock on susceptibility of orchard trees to Pseudomonas syringae. Plant Dis. Rep. 55:421-423.

3. Davis, J. R., and English, H. 1969. Factors related to the development of bacterial canker in peach. Phytopathology 59:588-595.

4. Day, L. H. 1947. The influence of rootstock on the occurrence and severity of bacterial canker. Am. Soc. Hortic. Sci. Proc. 50:100102.

5. English, H., Davis, J. R., and DeVay, J. E. 1980. Bacterial canker, an important decline disease of apricots and other stone fruits in California. Acta Hortic. 85:235-242.

6. English, H., DeVay, J. E., Schick, F. J., and Lownsbery, B. F. 1983. Reducing bacterial canker damage in 'French' prunes. Calif. Agric. 37:10-11.

7. Grubb, N. H. 1944. The comparative susceptibility of high- and low-worked cherry trees in the nursery to bacterial canker. Rep. East Malling Res. Stn. 1943:43-44.

8. Hattingh, M. J., Roos, I. M. M., and Mansvelt, E. L. 1989. Infection and systemic invasion of deciduous fruit trees by Pseudomonas syringae in South Africa. Plant Dis. 73:784-789.
9. Jones, A. L. 1971. Bacterial canker of sweet cherry in Michigan. Plant Dis. Rep. 55:961965.

10. Klement, Z., Rozsnyay, D. S., and Arsenijevic, M. 1974. Apoplexy of apricots: III. Relationship of winter frost and the bacterial canker and die-back of apricots. Acta Phytopathol. Acad. Sci. Hung. 9:35-45.

11. Klement, Z., Rozsnyay, D. S., Balo, E., PancZel, M., and Prileszky, G. 1984. The effect of cold on development of bacterial canker in apricot trees infected with Pseudomonas syringae pv. syringae. Physiol. Plant Pathol. 24:237-246.

12. Lownsbery, B. F., English, H., Noel, G. R., and Schick, F. J. 1977. Influence of Nemaguard and Lovell rootstocks and Macroposthonia xenoplax on bacterial canker of peach. J. Nematol. 9:221-224.

13. Melakeberhan, H., Sobiczewski, P., and Bird, G. W. 1992. Factors associated with the decline of sweet cherry trees in Michigan: nematodes, bacterial canker, nutrition, soil $\mathrm{pH}$, and winter injury. Plant Dis. 77:266-271.

14. Montgomery, H. B. S., Moore, M. H., and Hoblyn, T. N. 1943. A field trial of measures designed for the control of bacterial canker of Victoria plum trees. Rep. East Malling Res. Stn. 1942:53-61.

15. Ogawa, J. M., and English, H. 1991. Diseases of Temperate Zone Tree Fruit and Nut Crops. University of California, Division of Agriculture and Natural Resources, Oakland, CA. Publication 3345

16. Prunier, J. P., and Julian, J. P. 1999. Influence of rootstock and the height of grafting on the susceptibility of apricot cultivars to bacterial canker. Acta Hortic. 488:643-648.

17. Schofield, E. R., and Clift, L. F. 1959. Trials on the influence of stembuilders on bacterial canker of plum in the West Midlands. Plant Pathol. 8:115-120.

18. Steel, R. G. D., Torrie, J. H., and Dickey, D. A. 1997. Principles and Procedures of Statistics. A Biometrical Approach. McGrawHill, New York.

19. Weaver, D. J., and Wehunt, E. J. 1975. Effect of soil $\mathrm{pH}$ on susceptibility of peach to Pseudomonas syringae. Phytopathology 65:984-989.

20. Wormald, H. 1934. Bacterial diseases of stone fruit trees in Britain. V. Some field observations and experiments on plum bacterial canker. Rep. East Malling Res. Stn. 1933:147153.

21. Yadava, U. L., and Doud, S. L. 1989. Rootstock and scion influence growth, productivity, survival, and short life-related performance of peach trees. J. Am. Soc. Hortic. Sci. 114:875-880. 